\title{
Antiproliferative, antibacterial, and antioxidant activities of Bauhinia strychnifolia Craib aqueous extracts in gut and liver perspective
}

\author{
Suranat Phonghanpot ${ }^{1}$ and Faongchat Jarintanan ${ }^{2^{*}}$
}

\begin{abstract}
Background: Bauhinia strychnifolia Craib is an herb in Thai traditional medicine. Its decoction is traditionally used as an anticancer, antidiarrheal, and hangover remedy for centuries. Several studies described bioactivities of its organic solvent extracts, however, only few demonstrated the usefulness of the decoction. Here, we aimed to determine the bioactivities of Bauhinia strychnifolia Craib root and stem aqueous extracts in gut and liver perspective.

Methods: To achieve the goal, we performed MTT test, microscopic analyses, disc diffusion assay, broth microdilution assay, free radicals scavenging assays, and LC-MS analysis.

Results: We found that the extracts inhibited the growth of human hepatocellular carcinoma (HepG2) and colon adenocarcinoma (HT-29) cell lines. Moreover, they also inhibited the growth of gram-positive bacteria Staphylococcus aureus and Bacillus cereus but not inhibited the growth of gram-negative bacteria Escherichia coli and Pseudomonas aeruginosa. Furthermore, the extracts exhibited moderate antioxidant activity and increased GSH production in HepG2 cell line when compared with untreated. Our LC-MS analysis confirmed the existence of anticancer and antioxidant; 3,5,7,3',5'-pentahydroxyflavanonol-3-O-a-L-rhamnopyranoside and $\beta$-sitosterol, in the extracts.

Conclusion: The results from our study supported that the administration of Bauhinia strychnifolia Craib root and stem decoction would really aid colon or liver cancer patients and detoxify the alcoholic drunkard as it is claimed in Thai traditional medicine.
\end{abstract}

Keywords: Thai traditional medicine, Herbal medicine, Antiproliferation, Antimicrobial, Hangover remedy

\section{Background}

Bauhinia strychnifolia Craib is a climbing herb and a member of Caesalpiniaceae that have been used in Thai traditional medicine [1]. The young stem is brown grey in colour and changes toward red brown within the maturation. Length of the mature stem can be found at average

\footnotetext{
${ }^{*}$ Correspondence: faongchat.j@rsu.ac.th

${ }^{2}$ Faculty of Medical Technology, Rangsit University, 52/347 Muang Ake, Phaholyothin road, Lak Hok, Muang, Pathum Thani 12000, Thailand Full list of author information is available at the end of the article
}

of $5 \mathrm{~m}$. Rough root of Bauhinia strychnifolia Craib is usually seen in black but the inside is red brown. Bauhinia strychnifolia Craib sprouts cluster of flowers at the end of its stem, which can be seen during May to August. We can grow Bauhinia strychnifolia Craib by several methods, such as seeding, grafting, and clustering. Bauhinia strychnifolia Craib grows very fast on loam and needs moderate amount of water together with strong sunlight $[2,3]$.

A decoction prepared from Bauhinia strychnifolia Craib contains several beneficial medical properties and mainly 
used as anticancer, antidiarrheal, antihistamine, antiinflammation, antimalarial, fever remedy, hangover remedy, and insecticide antidote [3-7]. Considering anticancer activity, results from a study showed that Bauhinia strychnifolia Craib dichloromethane and ethanol extracts possess strong anticancer activity against A549 (lung), KB3-1 (cervical), MDA-MB-231 (breast), and SW480 (colon) cancer cell lines via MTT assay [4]. More recent, there was a study isolating chemical constituents from Bauhinia strychnifolia Craib root and stem ethanol extracts and analyzing for their anticancer activity. They successfully isolated 5 compounds, which exhibit cytotoxic activity against HeLa (cervical), HT-29 (colon), KB (oral), and MCF-7 (breast) cancer cell lines [3]. Latest in 2016, leaf ethanolic extracts of Bauhinia strychnifolia Craib were also analyzed for their anticancer activity against KKU-M156 (bile duct), LS174T (colon), and SW480 (colon) cell lines. The results showed that the vacuum liquid chromatography fraction of the ethanolic extracts could kill the mentioned human cancer cell lines [6].

Phytochemical study of the decoctions, which are prepared from different parts of the Bauhinia strychnifolia Craib, revealed the presence of several bioactive compounds including alkaloids, flavonoids, phenolic compounds, saponins, steroids, terpenoids, and triterpenes [8]. Administration of Bauhinia strychnifolia Craib decoction would aid the consumers gut to blood ecosystems consisting of inhibition of cell division, reduction of pathogenic microbes, and detoxification of free radicals. According to the traditional administration, Thai people in the Northeast of Thailand prepare Bauhinia strychnifolia Craib as a decoction rather than ethanol beverages [2, 3, 5-7]. However, the majority of the previous studies described the activities of organic solvent extracts of Bauhinia strychnifolia Craib against cancer cell lines. There were only few reports existing to explain the usefulness of Bauhinia strychnifolia Craib aqueous extract or its decoction. In this work, we aimed to analyze the impact of Bauhinia strychnifolia Craib root and stem aqueous extracts against colon and liver cell lines as a model of the traditional administration. To achieve the goal, we determined antiproliferative effect of the aqueous extracts against HepG2 and HT-29 cell lines, antibacterial activity against 4 major guts pathogenic bacterial strains, and antioxidant activity. The results of our study provided deeper understanding toward the benefits of Bauhinia strychnifolia Craib decoction.

\section{Methods}

\section{Preparation of Bauhinia strychnifolia Craib aqueous} extracts and samples

In this experiment, we obtained root and stem Bauhinia strychnifolia Craib aqueous extracts from
Assoc. Prof. Dr. Surapot Wongyai (Lecturer, Faculty of Oriental Medicine, Rangsit University). The plant materials were harvested, compared, and identified with the voucher specimen number BK No. 084965 (kept at BK Herbarium, Botanical Section, National Department of Agriculture, Thailand) by the harvester, Nirun Vipunngeun (Lecturer and Botanist, Department of Pharmacognosy, Faculty of Pharmacy, Rangsit University) from the Faculty of Pharmacy, Rangsit University's cultivation field before using in extract preparation. The extracts were prepared by boiling approximately $1 \mathrm{~kg}$ of the grinded root and stem in $5 \mathrm{~L}$ of water. Consequently, the filtered aqueous solutions were evaporated to obtain powder extracts using evaporator. For antibacterial and antioxidant analysis, the extracts were quantitated and dissolved in distilled water at different concentrations. For MTT and microscopic assays, the extracts were dissolved in DMEM (Gibco, USA) with $0.1 \%$ DMSO to obtain the desired final concentrations. The extracts were dissolved with methanol to the final concentration of $10 \mathrm{mg} / \mathrm{mL}$ for LC-MS analysis. Consequently, the samples were filtered through $0.25-\mu \mathrm{m}$ filters before subject $10 \mu \mathrm{L}$ of each into the machine.

\section{Determination of antiproliferative activity by MTT assay}

We used MTT assay to determine antiproliferative activity of the extracts against human hepatocellular carcinoma (HepG2 [HEPG2], ATCC HB-8065) and colon adenocarcinoma (HT-29, ATCC HTB-38) cell lines. We obtained the cell lines in collaboration with Asst. Prof. Dr. PotJanee Stimanote (Graduate Program in Biomedical Sciences, Faculty of Allied Health Science, Thammasat University) who purchased the cell lines from ATCC (ATCC, USA). We maintained the cell lines in DMEM, supplemented with 10\% FBS (Gibco, USA), $100 \mathrm{U} / \mathrm{mL}$ of penicillin-streptomycin (Gibco, USA). Following the standard protocol, in a 96-wells plate, approximately $5 \times 10^{4}$ cells were seeded and incubated $24 \mathrm{~h}$ at $37{ }^{\circ} \mathrm{C}$ in an atmosphere of humidified air with $5 \% \mathrm{CO}_{2}$. The medium in each well was then removed, replaced with the new medium containing the final concentrations of crude extract, and incubated for 24 more hours. For vehicle control, 0.1\% DMSO was used instead of the extracts. We then added $100 \mu \mathrm{L}$ of $2.5 \mathrm{mg} / \mathrm{mL}$ MTT solution into each well and incubated for $1 \mathrm{~h}$ at $37^{\circ} \mathrm{C}$. The purple formazan crystal were dissolved by addition of $100 \mu \mathrm{L}$ DMSO. Consequently, we read the absorbance at $570 \mathrm{~nm}$ using microplate reader. The percentage of surviving cells was calculated as \% cell viability $[9,10]$. Dose-response curves were constructed to achieve the $\mathrm{IC}_{50}$ values. All experimental data were derived from 3 independent experiments. 


\section{Phase contrast microscopic assay}

To investigate the effect of root and stem aqueous extracts toward HepG2 and HT-29 cell lines morphological changes, phase contrast microscopic analysis was performed. Briefly, $5 \times 10^{4}$ cells were seeded into 96-wells plate and incubated overnight. After that, the cell lines were treated with the root and stem extracts at their $\mathrm{IC}_{50}$ concentrations and incubated for $24 \mathrm{~h}$. For negative control, $0.1 \%$ DMSO was used instead of the extracts. The morphology of the cell lines were then examined using phase contrast inverted microscope at 10X magnification.

\section{Hoechst 33342 staining}

We examined the nuclei morphological changes of Hoechst 33342 stained HepG2 cells using fluorescenceinverted microscope. At the beginning, the HepG2 cells were plated at $1 \times 10^{5}$ cells $/ \mathrm{mL}$ in 4 -well chamber slide (Lab-Tek, USA) and incubated for overnight. The cells were treated with the root and stem extracts at their $\mathrm{IC}_{50}$ concentration and incubated for 6 and $12 \mathrm{~h}$. The negative (untreated) and positive (drug treated) controls were treated with $0.1 \%$ DMSO and $5 \mu \mathrm{M}$ doxorubicin, respectively. The cells were washed with PBS and incubated with $5 \mu \mathrm{M}$ Hoechst 33342 for $30 \mathrm{~min}$ in the dark at room temperature. The cells were then washed 3 times with PBS before examining their nuclei morphology under fluorescence-inverted microscope at 10X magnification.

\section{Disc diffusion assay}

In this work, we used Bacillus cereus ATCC14579, Escherichia coli ATCC25922, Pseudomonas aeruginosa ATCC27853, and Staphylococcus aureus ATCC25923 (ATCC, USA) as gut pathogenic representatives for screening of antibacterial activity of the extracts using disc-diffusion and broth microdilution assays. For disc diffusion assay, a single colony of each bacteria was selected, sub-cultured into $5 \mathrm{~mL} \mathrm{NB}$ (HiMedia, India), and incubated for $24 \mathrm{~h}$ at $37^{\circ} \mathrm{C}$. Each culture was then added into NSS until the turbidity reach McFarland's standard No. 0.5. The inoculated NSS (approximately $1.5 \times 10^{8}$ cells $/ \mathrm{mL}$ ) was swabbed on freshly prepared NA. Sterile $6 \mathrm{~mm}$ diameter filter paper discs (Whatman, UK) were impregnated with 2 and $5 \mathrm{mg}$ extracts before placing on the bacterial swabbed NA. After the incubation at $37^{\circ} \mathrm{C}$ for $24 \mathrm{~h}$, the antibacterial activity was evaluated by measuring the IZD. We used ampicillin $(10 \mu \mathrm{g} / \mathrm{disc})$, ceftriaxone $(30 \mu \mathrm{g} / \mathrm{disc})$, chloramphenicol $(30 \mu \mathrm{g} / \mathrm{disc})$, and rifampicin $(5 \mu \mathrm{g} / \mathrm{disc})$ (Oxoid, UK) as positive controls for inhibition of Escherichia coli, Pseudomonas aeruginosa, Bacillus cereus, and Staphylococcus aureus, respectively.

\section{Broth microdilution assay}

According to the positive results from disc diffusion assay, the MIC values of the extracts against Bacillus cereus and Staphylococcus aureus were determined by a service of Faculty of Pharmacy, Rangsit University. Following standard protocol with few adaptation, $100 \mu \mathrm{L}$ of two-fold serial dilutions of the root and stem aqueous extracts were prepared using MHB into 12 concentration ranging from 1028 to $0.5 \mu \mathrm{g} / \mathrm{mL}$ in 96 -wells plate. After that, $10 \mu \mathrm{L}$ of bacterial suspension (approximately $1.5 \times 10^{8}$ cells $/ \mathrm{mL}$ comparing with McFarland's standard No. 0.5) was added into each well. The plain medium wells without bacteria or bacterial wells without extract were also included in the plates serving as blanks and negative controls, respectively. For positive control, chloramphenicol and rifampicin were used instead of the extracts against Bacillus cereus and Staphylococcus aureus, respectively. Consequently, we cultured the plates at $37^{\circ} \mathrm{C}$ for $18 \mathrm{~h}$ before determining the MIC values by the unaided eye.

\section{ABTS radical scavenging assay}

Total antioxidant capacity measurement of the crude extracts was carried out using the Cayman's antioxidant assay kit (Cayman, USA). Following the manufacturer's protocol, $10 \mu \mathrm{L}$ of each Trolox standard, $10 \mu \mathrm{L}$ of metmyoglobin, and $150 \mu \mathrm{L}$ of chromogen was added into the provided 96-wells plate for duplication. For the sample wells, $10 \mu \mathrm{L}$ of $100 \mathrm{mg} / \mathrm{mL}$ root or stem extracts, $10 \mu \mathrm{L}$ of metmyoglobin, and $150 \mu \mathrm{L}$ of chromogen were added into the plate for triplication. The reaction was initiated by addition of $40 \mu \mathrm{L}$ of $\mathrm{H}_{2} \mathrm{O}_{2}$ working solution into each well that was being used. After covering the plate with the plate cover, the plate was shaken and incubated for $5 \mathrm{~min}$ in room temperature. We, then, read the absorbance of the mixtures at $750 \mathrm{~nm}$. Antioxidant capacity of the extracts was calculated into $\mu \mathrm{mol} / \mathrm{g}$ Trolox equivalent using standard calibration curve.

\section{Determination of total GSH}

The colorimetric GSH+GSSG/GSH assay kit (Abcam, USA) was used for evaluating GSH amount inside the extracts treated HepG2 cell line. According to the manufacturer's instructions, approximately $8 \times 10^{5} \mathrm{HepG} 2$ cells were seeded into each well of 6-wells plate. The cells were pretreated with 0.05 or $0.10 \mathrm{mM} \mathrm{H}_{2} \mathrm{O}_{2}$ for $2 \mathrm{~h}$ following by the treatment of stem $(0,0.15$, and $0.3 \mathrm{mg} / \mathrm{mL})$ or root $(0,0.3$, and $0.6 \mathrm{mg} / \mathrm{mL})$ extracts for $24 \mathrm{~h}$. After harvesting the cells, they were washed with ice-cold PBS, centrifuged to remove supernatant, and lysed with GSH buffer. After $10 \mathrm{~min}$ incubation, 5\% SSA was added, centrifuged, and then collected the supernatant further analysis. The $160 \mu \mathrm{L}$ 
of reaction mix solution was added to each well of 96-wells plate and incubated for $10 \mathrm{~min}$. After that, we added $20 \mu \mathrm{L}$ of either the GSH standard solutions or the samples into each well and incubated in room temperature for $10 \mathrm{~min}$. Finally, the $20 \mu \mathrm{L}$ substrate solution was added into each well and incubated at room temperature for $10 \mathrm{~min}$. Consequently, we determined the absorbance at $405 \mathrm{~nm}$ using microplate reader. Concentration of GSH in the sample was calculated by linear regression with the standard GSH calibration curve.

\section{Liquid chromatography tandem mass spectrometry (LC-MS) analysis}

We analysed the chemical composition inside the root and stem aqueous extracts by the service of RSU Scientific and Technological Research Equipment Center (Rangsit University, Thailand). To separate the chemical constituents of the extracts, we used Vertisep reverse phase column C18 (Vertichrom, Thailand) equipped with UltiMate 3000 UHPLC systems (Thermo Scientific, USA). Using mobile phase as water (A) and acetonitrile (B) with flow rate of $0.3 \mathrm{~mL} / \mathrm{minute}$, the following step gradient condition was applied for liquid chromatography operation: 0-20 min 5\% B; 20-30 min from 5 to $50 \% \mathrm{~B}$; 30-50 min $50 \% \mathrm{~B}$; $50-60 \mathrm{~min}$ from 50 to $80 \% \mathrm{~B}$; $60-80 \mathrm{~min} 80 \% \mathrm{~B}$; $80-90 \mathrm{~min}$ from 80 to $100 \% \mathrm{~B} ; 90-120 \mathrm{~min} 100 \% \mathrm{~B} ; 120-140 \mathrm{~min}$ from 100 to $5 \%$ $\mathrm{B}$; and the column was equilibrated for $140-155 \mathrm{~min}$ with $5 \%$ B before the next run. For electrospray ionization ion trap mass spectrometry, we used amaZon SL systems (Bruker, USA) with the following parameters: capillary voltage $+4500 \mathrm{~V}$, source temperature $220^{\circ} \mathrm{C}$, Helium desolvation gas flow $7 \mathrm{~L} /$ minute, and nebulizer pressure 2.0 bar. For full scan MS analysis, the spectra were recorded in the negative mode in the range of $\mathrm{m} / \mathrm{z} 200-500$.

\section{Statistical analyses}

In general, the independent triplicate assay values were expressed in the form of mean \pm SEM. We used one-way ANOVA following by Tukey HSD and Friedman tests to confirm the significant differences between DMSO control group with root and stem aqueous extract groups in all assays. When the $p$-value $<0.05$, they were considered as statistically significant. All of the statistical analyses were performed using Microsoft Excel, Statistics Kingdom, and Statology online tools (https://www.statskingdom.com, https://www.statology.org).

\section{Results}

Antiproliferative activity of Bauhinia strychnifolia Craib aqueous extracts against the growth of HepG2 and HT-29 cell lines

We determined the antiproliferative activity of the Bauhinia strychnifolia Craib root and stem aqueous extracts against HepG2 and HT-29 cell lines, which represent hepatocellular carcinoma and colon adenocarcinoma, respectively. According to the different sensitivity of the cell lines to the extracts, the final concentrations of each extract against each cell line in this work were 0 to $1.50 \mathrm{mg} / \mathrm{mL}$ and 0 to $6.00 \mathrm{mg} / \mathrm{mL}$ for HepG2 and HT-29 cell lines, respectively. Using MTT assay, the \% cell viabilities of each extract against each cell were calculated and plotted in graphical representation. Obviously, the root and stem aqueous extracts of Bauhinia strychnifolia Craib reduced proliferation of HepG2 and HT-29 (Fig. 1). $\mathrm{IC}_{50}$ values of root and stem extracts against the growth of HepG2 cell line were $0.22 \pm 0.01$ ( $p$-value $<0.001)$ and $0.30 \pm 0.01$ ( $p$-value $<0.001) \mathrm{mg} / \mathrm{mL}$, respectively. In addition, $\mathrm{IC}_{50}$ values of root and stem extracts against the growth of HT-29 cell line were $1.13 \pm 0.38$ ( $p$-value $<0.001)$ and $1.50 \pm 0.32(p$-value $<0.001) \mathrm{mg} / \mathrm{mL}$, respectively (Table 1 ).

\section{Observation of apoptosis liked behavior by microscopic analysis}

We used inverted microscope to observe the morphology of the extract treated HepG2 and HT-29 cell lines comparing with their negative control (0.1\% DMSO). We found that the root and stem aqueous extracts treated HepG2 and HT-29 cell lines changed their morphology when comparing with untreated control cell lines. The morphologies including cell blebbing, shrinkage, and formation of late apoptosis liked cells were clearly observed in all $24 \mathrm{~h}$ extracts treated cell lines at their $\mathrm{IC}_{50}$ concentrations (Fig. 2). To prove our hypothesis on apoptosis, we then cultured HepG2 cell line, treated the cell line with extracts, and stained the cell line by Hoechst 33342 stain in cell culture chamber slide. The fluorescent microscopic analysis showed the nuclear condensation behavior of the extract treated HepG2 cell line at $\mathrm{IC}_{50}$ concentrations $(0.22 \mathrm{mg} / \mathrm{mL}$ of root extract and $0.30 \mathrm{mg} /$ $\mathrm{mL}$ of stem extract), but not in negative control untreated HepG2 cell line (0.1\% DMSO) (Fig. 3).

\section{Antibacterial activity of the Bauhinia strychnifolia Craib aqueous extracts}

We determined antibacterial activity of root and stem extracts against 4 important human gut ecosystem pathogens. Among these pathogens, Bacillus cereus and Staphylococcus aureus represented gram-positive bacteria while Escherichia coli and Pseudomonas aeruginosa represent gram-negative bacteria. The disc diffusion assay results obviously showed that the Bauhinia strychnifolia Craib root and stem extracts inhibited the growth of Bacillus cereus and Staphylococcus aureus but cannot inhibited the growth of Escherichia coli and Pseudomonas aeruginosa (see Additional file 1). 

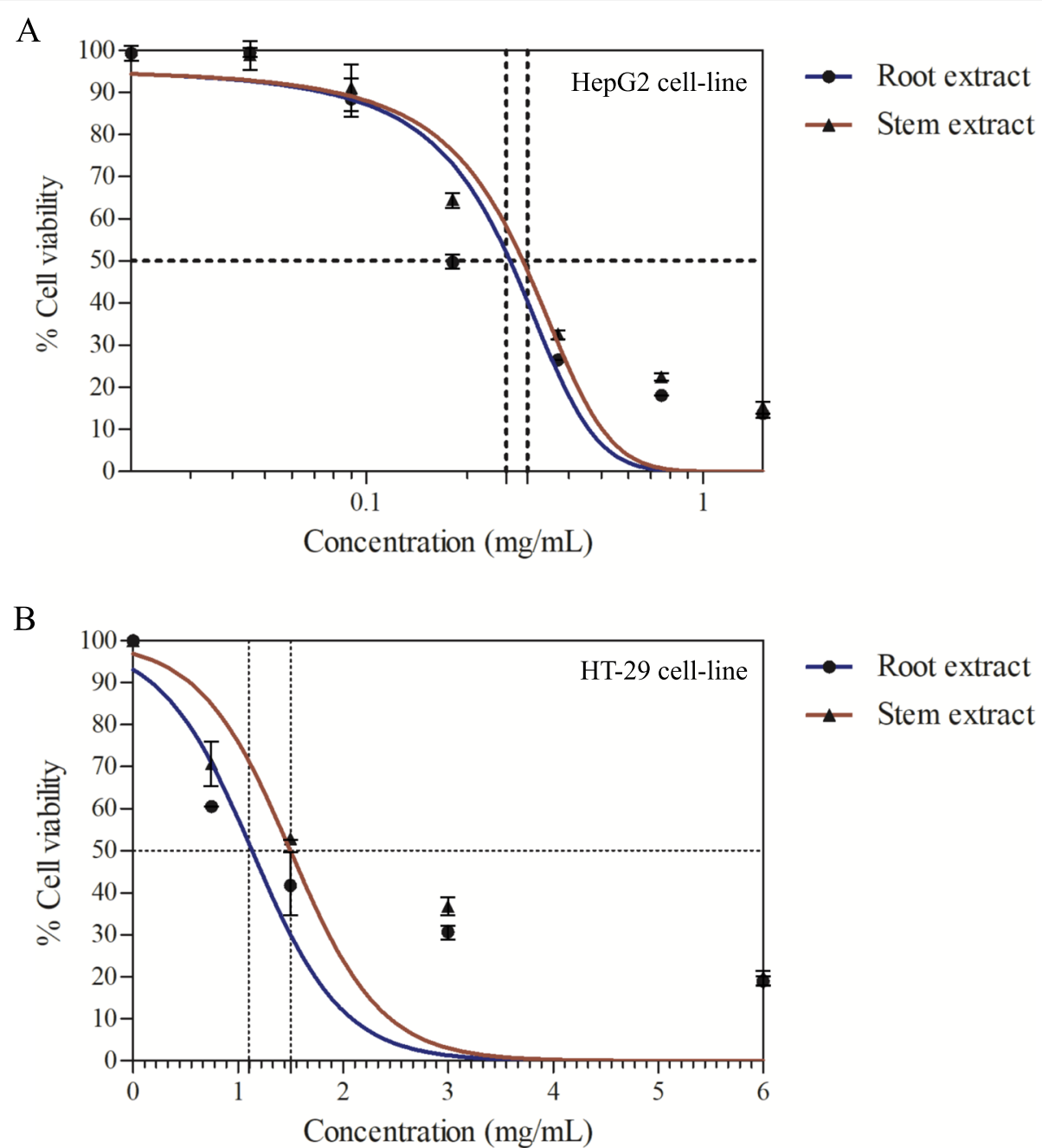

Fig. 1 Graphical plot of aqueous extracts concentrations and calculated \% cell viabilities relative with control untreated cell lines. A MTT test of root and stem aqueous extracts against HepG2 cell line. B MTT test of root and stem aqueous extracts against HT-29 cell line

Table $1 \quad C_{50}$ of root and stem aqueous extracts against HepG2 and HT-29 cell lines

\begin{tabular}{lll}
\hline Cell line & \multicolumn{2}{l}{$\mathbf{I C}_{\mathbf{5 0}}(\mathbf{m g} / \mathbf{m L})(\mathbf{m e a n} \pm \mathbf{S E M})$} \\
\cline { 2 - 3 } & Root extract & Stem extract \\
\hline HepG2 & $0.22 \pm 0.01$ & $0.30 \pm 0.01$ \\
HT-29 & $1.13 \pm 0.38$ & $1.50 \pm 0.32$ \\
\hline
\end{tabular}

Consequently, we determined the MIC values of root and stem aqueous extracts against Bacillus cereus and Staphylococcus aureus. The broth microdilution assay results showed the similar MIC values of all analyses at $128 \mu \mathrm{g} / \mathrm{mL}$ (Table 2).

\section{Antioxidant activity of Bauhinia strychnifolia Craib aqueous} extracts

We first determined total antioxidant capacity of the Bauhinia strychnifolia Craib root and stem extracts using Cayman's ABTS kit. We found that the root and stem extracts possessed total antioxidant capacity (Trolox equivalent) at $1.66 \pm 0.99$ and $2.51 \pm 0.10 \mu \mathrm{mol} / \mathrm{g}$ extract $(p$-value $<0.001)$, respectively. Furthermore, we determined the cellular response of the root and stem extracts treated oxidative stressed HepG2 cells comparing with the untreated oxidative stressed cells using Abcam's GSH + GSSG/ GSH assay kit. We hypothesized that the extract treated oxidative stressed cells produced more GSH than the control oxidative stressed cells for scavenging of free radicals. The result confirmed the increasing of GSH production from $43.58 \pm 0.17 \mathrm{ng}$ in control $0.05 \mathrm{mM}$ 


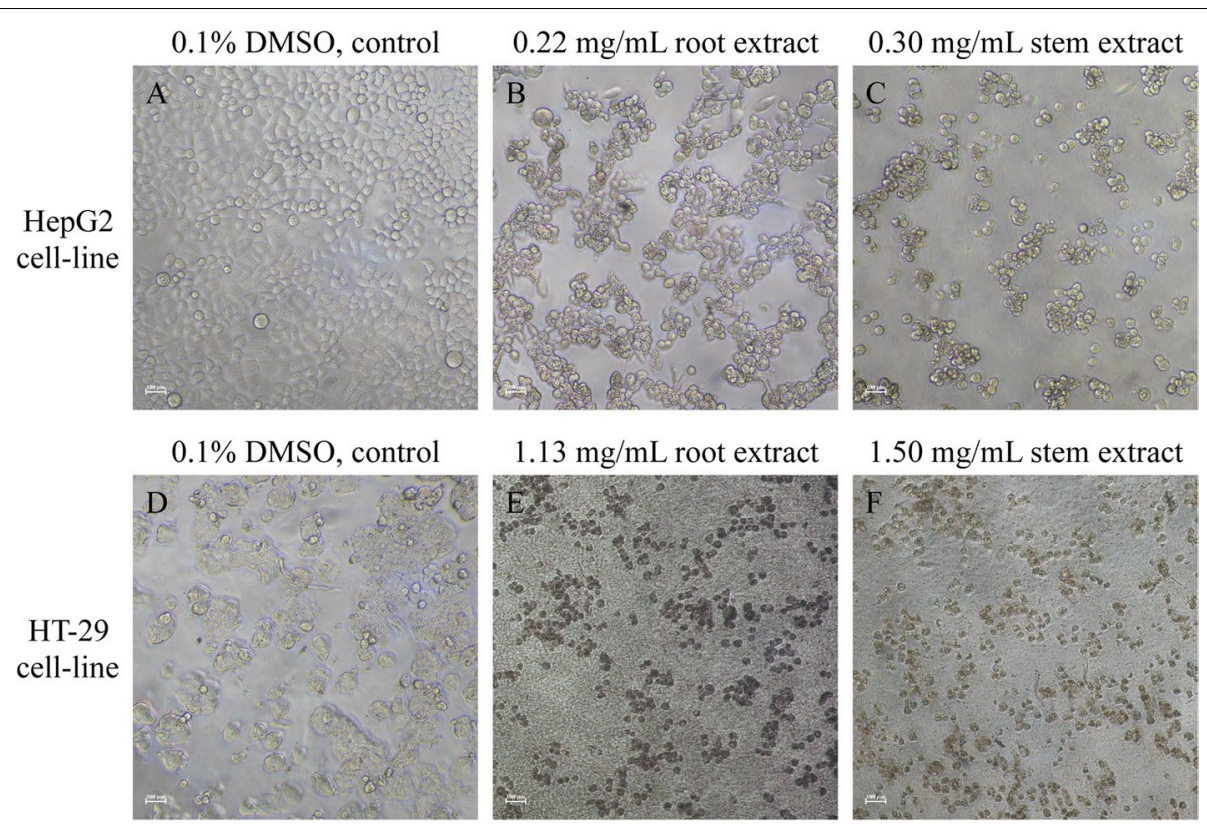

Fig. 2 Phase contrast microscopic analysis of extracts treated HepG2 and HT-29 cell lines. A HepG2 cell line treated with 0.1\% DMSO. B HepG2 cell line treated with $0.22 \mathrm{mg} / \mathrm{mL}$ root extract. C HepG2 cell line treated with 0.30 stem extract. D HT-29 cell line treated with $0.1 \%$ DMSO. E HT-29 cell line treated with $1.13 \mathrm{mg} / \mathrm{mL}$ root extract. $\mathbf{F}$ HT-29 cell line treated with $1.50 \mathrm{mg} / \mathrm{mL}$ stem extract

$\mathrm{H}_{2} \mathrm{O}_{2}$ oxidative stressed HepG2 cells to $46.00 \pm 0.07$ $(p$-value $<0.001)$ and $44.87 \pm 0.20$ ( $p$-value $<0.001)$ $\mathrm{ng}$ in $0.3 \mathrm{mg}$ root and $0.15 \mathrm{mg}$ stem extract treated $0.05 \mathrm{mM} \mathrm{H}_{2} \mathrm{O}_{2}$ oxidative stressed HepG2 cells, respectively. However, at high concentration of $\mathrm{H}_{2} \mathrm{O}_{2}(0.1 \mathrm{mM})$ or high concentration of extracts $(0.6 \mathrm{mg}$ root extract or $0.3 \mathrm{mg}$ stem extract), the extract treated $\mathrm{H}_{2} \mathrm{O}_{2}$ oxidative stressed HepG2 cells entered apoptosis phase and produced less GSH than the control $\mathrm{H}_{2} \mathrm{O}_{2}$ oxidative stressed HepG2 cells ( $p$-value <0.05) (Fig. 4).

\section{Major chemical constituents in the Bauhinia strychnifolia Craib root and stem aqueous extracts}

We would like to elucidate the chemical composition inside the root and stem aqueous extracts whether they have similar major compositions as the alcohol extracts or not. Using LC-MS analysis, we found that the Bauhinia strychnifolia Craib root and stem aqueous extracts had the similar major masses of compounds to the alcohol extracts in previous study [3]. We found the $[\mathrm{M}-\mathrm{H}]^{-}$mass of 3,5,7,3',5'-pentahydroxyflavanonol-3O- $\alpha$-L-rhamnopyranoside at calculated $449 \mathrm{~m} / \mathrm{z}$ (found $448.9 \mathrm{~m} / \mathrm{z}$ ) in root and $\beta$-sitosterol at calculated $413 \mathrm{~m} / \mathrm{z}$ (found $412.6 \mathrm{~m} / \mathrm{z}$ ) in stem extracts. Moreover, there was another major $[\mathrm{M}-\mathrm{H}]^{-}$mass shown at $488.5 \mathrm{~m} / \mathrm{z}$ representing an unknown compound found in Bauhinia strychnifolia Craib stem extract (Fig. 5).

\section{Discussion}

Our results confirmed that both Bauhinia strychnifolia Craib root and stem aqueous extracts could inhibit the growth of HepG2 and HT-29 cell lines. In addition, we found that the root aqueous extract better inhibited the growth of the cell lines than stem aqueous extract. The results reflected the different compositions and/or ratio of chemicals, especially for antiproliferative compounds, between the parts of the plant. The results were similar to the analysis of anticancer activity of Bauhinia strychnifolia Craib dichloromethane, ethanol, hexane, and aqueous extracts in 2012. Furthermore, 5 pure compounds were isolated from Bauhinia strychnifolia Craib ethanol fraction and identified for their anticancer activity in 2013. The studies confirmed that the extracts and isolated pure compounds inhibited the growth of A549, HT-29, HeLa, KB, KB3-1, MCF-7, MDA-MB-231, and SW480 cell lines; however, they did yet describe the mechanism of inhibition [3, 4]. In addition to MTT assay, our phase contrast microscopic analysis together with Hoechst 33342 staining suggested that Bauhinia strychnifolia Craib root and stem aqueous extracts would likely inhibit the growth of HepG2 and HT-29 cell lines through apoptosis pathway. Accordingly, the administration of Bauhinia strychnifolia Craib root and stem decoction could really aid cancer patients with the hepatocellular carcinoma and colon adenocarcinoma as claimed in Thai traditional medicine. 


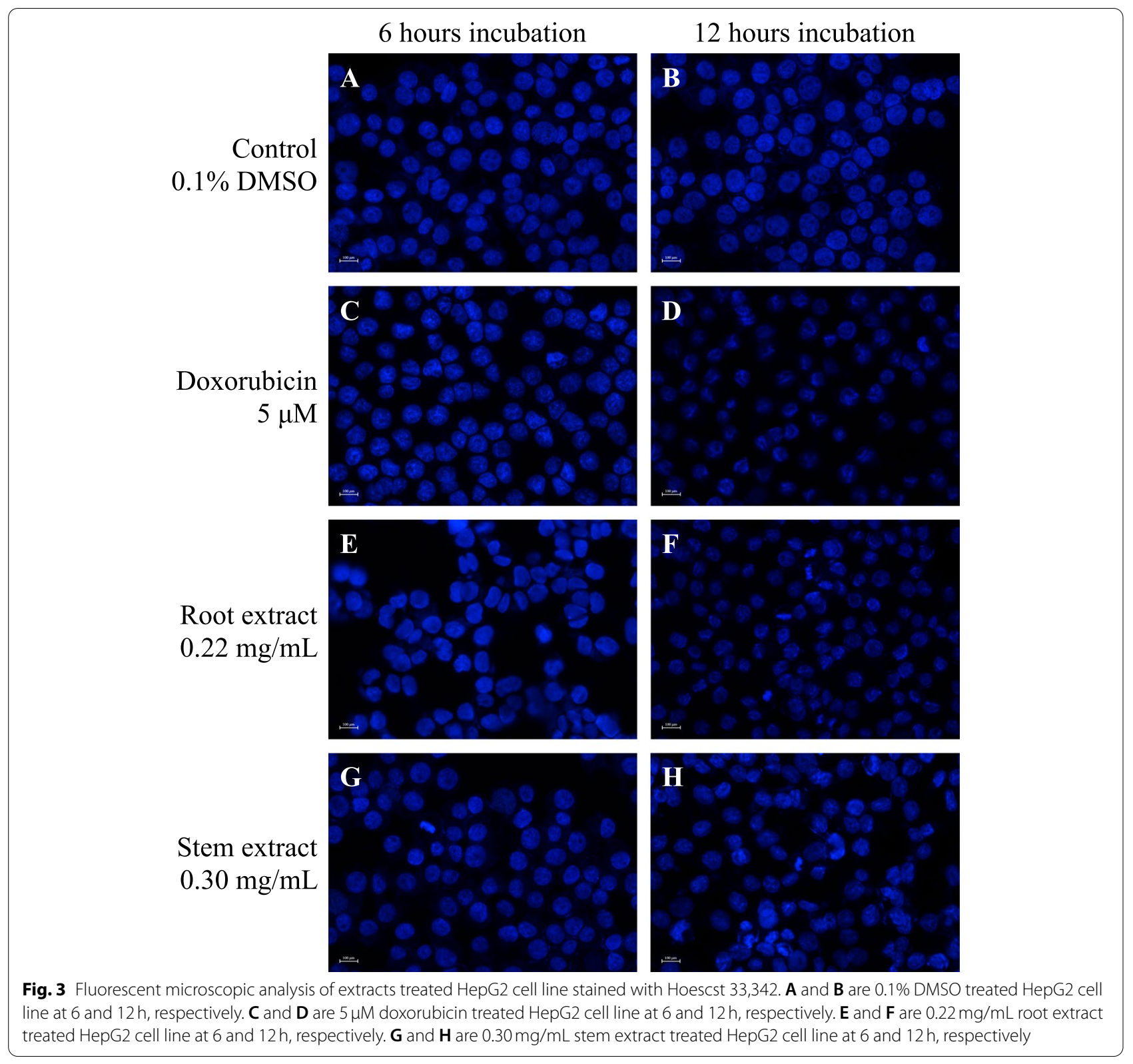

Table 2 IZD values from the disc diffusion assay and MIC values from the broth microdilution assay

\begin{tabular}{|c|c|c|c|c|c|c|c|c|}
\hline \multirow[t]{3}{*}{ Bacteria } & \multicolumn{5}{|c|}{ IZD $(\mathrm{mm})($ mean \pm SEM) } & \multicolumn{3}{|l|}{$\mathrm{MIC}(\mu \mathrm{g} / \mathrm{mL})$} \\
\hline & \multicolumn{2}{|c|}{ Root extract } & \multicolumn{2}{|c|}{ Stem extract } & \multirow[t]{2}{*}{ Positive control $^{a}$} & \multirow[t]{2}{*}{ Root extract } & \multirow[t]{2}{*}{ Stem extract } & \multirow{2}{*}{$\begin{array}{l}\text { Positive } \\
\text { controlb }^{\text {b }}\end{array}$} \\
\hline & $2 \mathrm{mg}$ & $5 \mathrm{mg}$ & $2 \mathrm{mg}$ & $5 \mathrm{mg}$ & & & & \\
\hline Bacillus cereus & $11.6 \pm 0.7$ & $14.4 \pm 1.2$ & $10.4 \pm 0.7$ & $13.4 \pm 1.2$ & $19.2 \pm 2.0$ & 128 & 128 & 8 \\
\hline Escherichia coli & N/A & N/A & N/A & N/A & $17.0 \pm 1.6$ & ND & ND & ND \\
\hline Pseudomonas aeruginosa & N/A & N/A & N/A & N/A & $20.4 \pm 1.9$ & ND & ND & ND \\
\hline Staphylococcus aureus & $11.2 \pm 0.7$ & $12.4 \pm 0.7$ & $9.2 \pm 0.7$ & $11.2 \pm 0.7$ & $31.0 \pm 1.6$ & 128 & 128 & 8 \\
\hline
\end{tabular}

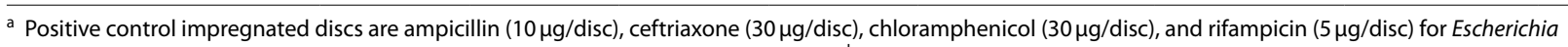
coli, Pseudomonas aeruginosa, Bacillus cereus, and Staphylococcus aureus, respectively. ${ }^{\mathrm{b}}$ Positive control are chloramphenicol and rifampicin for Bacillus cereus, and Staphylococcus aureus, respectively. N/A value is defined as zero. ND means not determined 


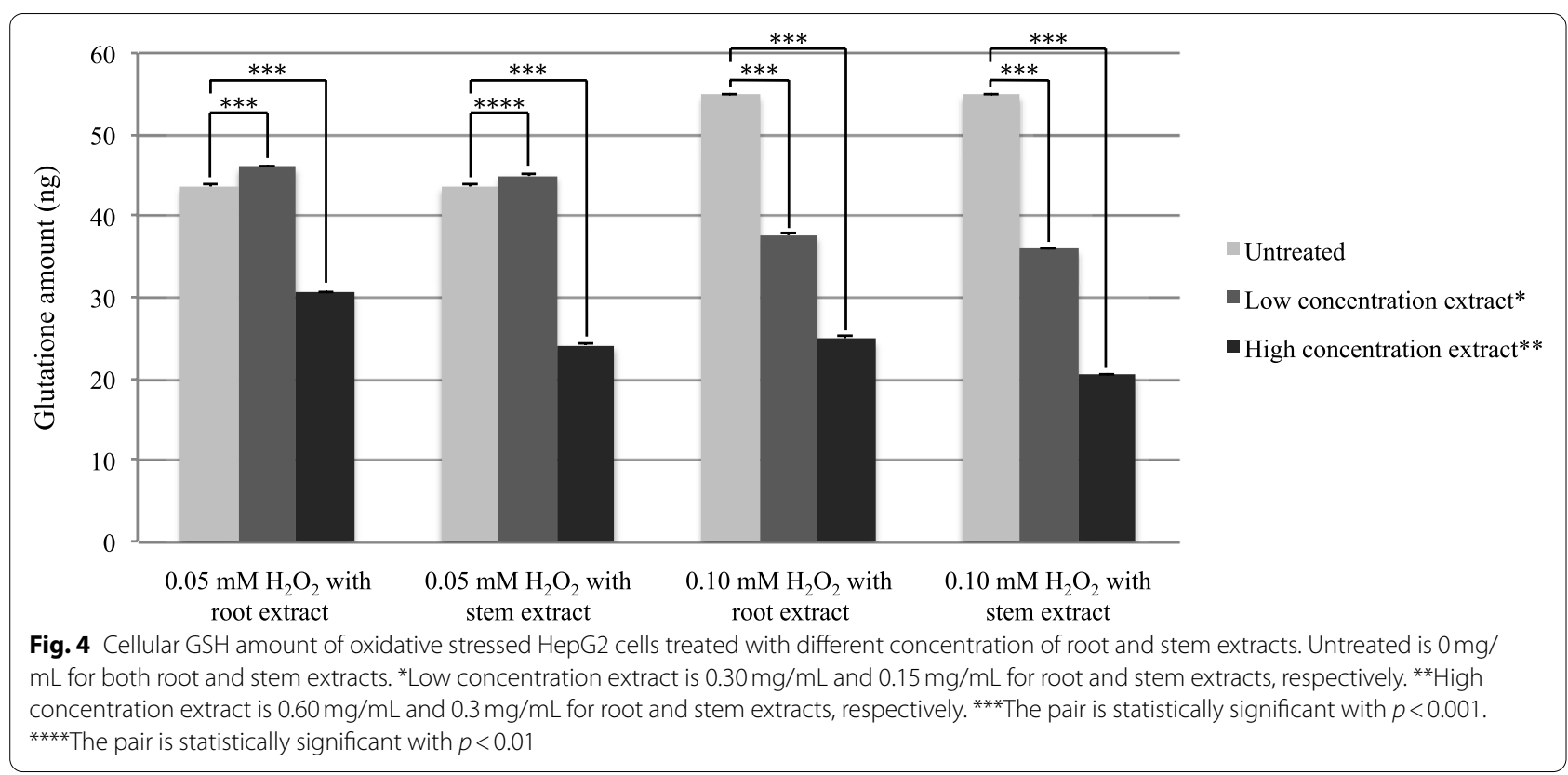

In some cancer patients, especially with the colon cancer wound infected by opportunistic pathogens, they could suffer more than the others [11]. There were some evidences showing that the administration of Bauhinia strychnifolia Craib decoction could reduce diarrhea causing by gut ecosystem pathogens [2]. Accordingly, we determined the antibacterial activity of the extracts against 4 important gut pathogens including 2 g-positive bacteria Bacillus cereus and Staphylococcus aureus and 2g-negative bacteria Escherichia coli and Pseudomonas aeruginosa. We found that the Bauhinia strychnifolia Craib root and stem aqueous extracts could kill the gram-positive bacteria but not killed gram-negative bacteria. There was no previous study on the antibacterial activity analysis of Bauhinia strychnifolia Craib; our study was the first report for the selective inhibition of root and stem aqueous extracts against gram-positive bacteria Bacillus cereus and Staphylococcus aureus. Considering MIC values, the inhibition activity of root and stem aqueous extracts $(128 \mu \mathrm{g} / \mathrm{mL})$ against Staphylococcus aureus is comparable with known diarrheal treating plants such as polyphenol extracts of wild blackberry (Rubus fruticosus, $125 \mu \mathrm{g} / \mathrm{mL}$ ), blackthorn (Prunus spinosa L., $125 \mu \mathrm{g} / \mathrm{mL}$ ) and European cornel (Cornus mas, $125 \mu \mathrm{g} / \mathrm{mL}$ ) [12] but better than aqueous extracts of lime (Citrus aurantifolia, $256 \mu \mathrm{g} / \mathrm{mL}$ ) [13] and green tea (Camellia sinensis, $400 \mu \mathrm{g} / \mathrm{mL}$ ) [14]. Our results supported the hypothesis that the administration of Bauhinia strychnifolia Craib decoction would help reducing diarrhea causing by the gram-positive pathogens.
We noticed that hangover remedy was one of the major uses of Bauhinia strychnifolia Craib decoction in Thai traditional medicine [3, 5-7]. The detoxification processes would be related with antioxidation activity of the antioxidant compounds or cellular free radical scavenging pathway stimulator existed in the decoction. We performed ABTS and GSH antioxidant assays to confirm the presence of the antioxidants in Bauhinia strychnifolia Craib root and stem aqueous extracts. The results from our ABTS assay suggested that the root and stem aqueous extracts had comparable total antioxidant capacity with several vegetables and fruits analysed in 2007. Bauhinia strychnifolia Craib root and stem aqueous extracts had Trolox equivalent values $(1.66 \pm 0.99$ and $2.51 \pm 0.10 \mu \mathrm{mol} / \mathrm{g}$ extract for root and stem extracts, respectively) similar to red onion $(1.76 \mu \mathrm{mol} / \mathrm{g})$ and tomato $(1.17 \mu \mathrm{mol} / \mathrm{g}), 3$ times higher than spinach $(0.28 \mu \mathrm{mol} / \mathrm{g})$, but 3 times less than orange $(5.06 \mu \mathrm{mol} / \mathrm{g})$ [15]. After treating oxidative stressed HepG2 cell line with the root and stem aqueous extracts and determining GSH production inside the cell, we found that the low concentration extracts treated HepG2 cell line produce higher GSH than the untreated oxidative stressed HepG2 cell line. However, the oxidative stressed HepG2 cell line entered apoptosis after we treated them with high concentration extracts. Consequently, the high concentration extracts treated oxidative stressed cells produced lower amount of GSH than the untreated cells. At this point, we could assume that treating HepG2 cell line with Bauhinia strychnifolia Craib root and stem aqueous extracts at low concentration stimulating the cellular free 
Root extract, negative mode $[\mathrm{M}-\mathrm{H}]^{-}$

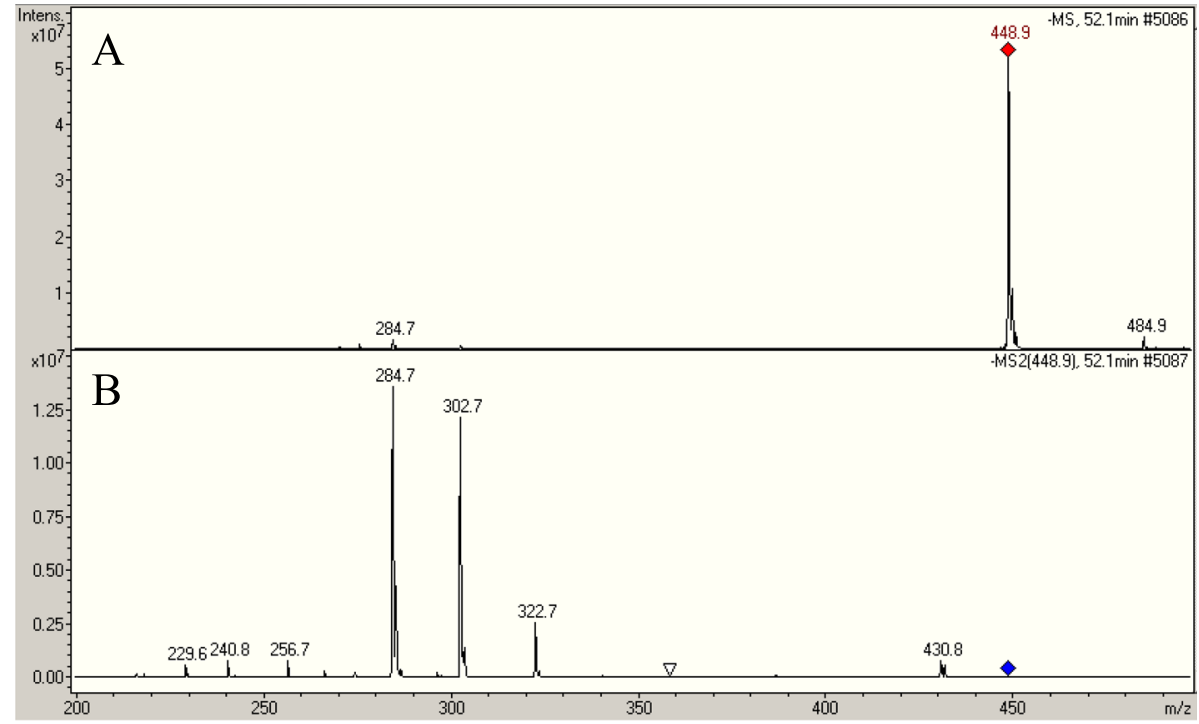

Stem extract, negative mode $[\mathrm{M}-\mathrm{H}]$

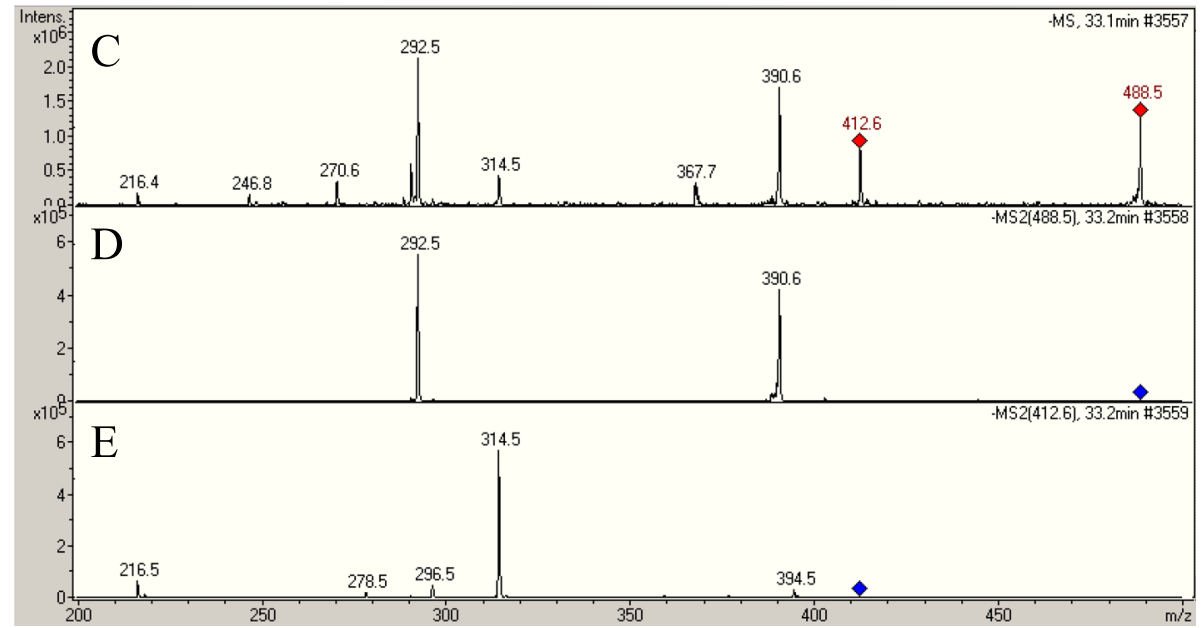

Fig. 5 LC-MS analysis of root and stem extracts for elucidation of their major compositions. For root extract, (A) a major compound found at [M-H] ${ }^{-}$ $448.9 \mathrm{~m} / \mathrm{z}$ and $(\mathbf{B})$ its matched fragmented masses of 3,5,7,3',5'-pentahydroxyflavanonol-3-O-a-L-rhamnopyranoside. For stem extract, (C) a major compound found at $[\mathrm{M}-\mathrm{H}]^{-} 412.6 \mathrm{~m} / \mathrm{z}$ and $(\mathbf{E})$ its matched fragmented masses of $\beta$-sitosterol together with (D) unmatched fragmented masses of a unknown compound found at $[\mathrm{M}-\mathrm{H}]^{-}-488.5 \mathrm{~m} / \mathrm{z}$

radical scavenging pathway via production of GSH similar to several previous studies [16-20]. Together, it might be the reason why we would be able to use Bauhinia strychnifolia Craib decoction as hangover remedy.

According to the study in 2013, 5 major metabolites from ethanol fraction of Bauhinia srtychnifolia Criab were isolated, purified, and determined for their anticancer activity against several cell lines. We suspected that some of these metabolites might be presented in the Bauhinia strychnifolia Craib root and stem aqueous extracts. We did LC-MS analysis to confirm the presence of the 5 compounds. For root extract, we found $\quad 3,5,7,3^{\prime}, 5^{\prime}$-pentahydroxyflavanonol-3-O- $\alpha-\mathrm{L}-$ rhamnopyranoside, one among the 5 isolated compounds, as a major metabolite. The metabolite had very high potent cytotoxicity against $\mathrm{HeLa}\left(\mathrm{IC}_{50} 0.0692 \mu \mathrm{g} /\right.$ $\mathrm{mL}), \mathrm{HT}-29\left(\mathrm{IC}_{50} 0.00217 \mu \mathrm{g} / \mathrm{mL}\right), \mathrm{KB}\left(\mathrm{IC}_{50} 0.00054 \mu \mathrm{g} /\right.$ $\mathrm{mL})$, and MCF-7 $\left(\mathrm{IC}_{50} 0.0585 \mu \mathrm{g} / \mathrm{mL}\right)$ cell lines [3]. A study in 2019 suggested that the compound could inhibit the activity of $\alpha$-glucosidase with $\mathrm{IC}_{50}$ of $0.98 \mathrm{mg} /$ $\mathrm{mL}$. According to the bioactivity, the compound was proposed as a potent antidiabetic drug [7]. Not only 
that, a molecular docking study in 2020 revealed that the compound could bind and inhibit cyclin-dependent protein kinase 2/CDK-2 inducing the cell lines to enter apoptosis phase [21]. Obviously, Bauhinia strychnifolia Craib root aqueous extract, which contain $\quad 3,5,7,3^{\prime}, 5^{\prime}$-pentahydroxyflavanonol-3-O- $\alpha$ - Lrhamnopyranoside as a major metabolite in our study, should be able to exhibit the antiproliferative activity against both HepG2 and HT-29 cell lines.

For stem extract, we found $\beta$-sitosterol as a major compound together with an unknown metabolite [3]. For $\beta$-sitosterol, it is a regarded as a safe nutritional supplement that can be sold commercially in the market [22]. It was recognized to possess several bioactivities including anti-nociceptive [23], anxiolytic \& sedative effects [24], analgesic [25], immune modulatory [26], antimicrobial [27], anti-inflammatory [28], protective effect against non-alcoholic fatty liver disease [29], lipid lowering [30], hepatoprotective [31], protective effect on respiratory diseases [32], wound healing [33], antidiabetic [34], antioxidant [35], and anticancer [36]. As an anticancer, it could inhibit the growth of HeLa, HT-29, KB, and MCF-7 cell lines with moderate $\mathrm{IC}_{50}$ values ranging from 0.099 to $1.49 \mu \mathrm{g} / \mathrm{mL}$ [3]. We found that Bauhinia strychnifolia Craib stem aqueous extract exhibited moderate free radicals scavenging activity similar to several other plants that have $\beta$-sitosterol as major component including fir, purple yam, water pepper, nutmeg, white mustard, anise, coriander, and caraway [37]. Theoretically, $\beta$-sitosterol should reverts the GSH/oxidized GSH ratio value by GSH turnover (reduction of oxidized GSH back to GSH). However, a study in 2005 revealed that $\beta$-sitosterol is a key stimulator involving in a protective intracellular antioxidant defense mechanism. It modulates antioxidant enzymes in estrogen receptor/PI3-kinase-dependent pathway, thus increasing GSH production in the $\beta$-sitosterol treated macrophage cells [38]. In 2011, streptozotocin-induced diabetic rats were treated with $\beta$-sitosterol. The increasing of GSH level in pancreatic tissue was detected similar to the result from our study [39]. Moreover, a recent study in 2017 also suggested that $\beta$-sitosterol could increase production of GSH and inhibited cholinesterase in sub-strain of transgenic Alzheimer's disease mice [40]. The production of GSH detected in our study could be a result from free radical scavenging activity and/or stimulation of cellular defence mechanism by $\beta$-sitosterol similar to the previous studies.

\section{Conclusion}

The decoction prepared from root and stem of Bauhinia strychnifolia Craib could inhibit the growth of hepatocellular carcinoma and colon adenocarcinoma cell lines with impressed $\mathrm{IC}_{50}$ values. In addition, they could also inhibit the growth of gram-positive bacterial pathogens such as Staphylococcus aureus and Bacillus cereus. Moreover, the ABTS and GSH assays confirmed the existence of antioxidant and/ or cellular free radical protective stimulant inside the root and stem aqueous extracts. Our LC-MS analyses suggested that the root and stem decoctions contained $\quad 3,5,7,3^{\prime}, 5^{\prime}$-pentahydroxyflavanonol-3-O- $\alpha$ L-rhamnopyranoside and $\beta$-sitosterol, which exhibit potent anticancer and antioxidant bioactivities. Altogether, the results of our analyses supported that administrating Bauhinia strychnifolia Craib root and stem decoctions would give beneficial effects on both colon and liver ecosystem as the claimed in Thai traditional medicine.

\section{Abbreviations \\ ABTS: 2,2'-azino-di 3-ethylbenthiazolinesulfonate; ANOVA: Analysis of vari- ance; ATCC: American Type Culture Collection; DMEM: Dulbecco's modified eagle medium; DMSO: Dimethyl sulfoxide; FBS: Fetal bovine serum; GSH: Glutathione; GSSG: Glutathione disulfide; $I_{50}$ : The half maximal inhibitory concentration; IZD: Inhibition zone diameter; LC-MS: Liquid chromatogra- phy-mass spectrometry; MHB: Mueller-Hinton broth; MIC: Minimal inhibitory concentration; MTT: 3-(4,5-dimethylthiazol-2-yl)-2,5-diphenyl tetrazolium bromide; N/A: Not available or zero; NA: Nutrient agar; NB: Nutrient broth; ND: Not determined; NSS: Normal saline solution; SEM: Standard error of mean; SRB: Sulforhodamine B; SSA: Sulfosalicylic acid solution.}

\section{Supplementary Information}

The online version contains supplementary material available at https://doi. org/10.1186/s12906-021-03448-2.

\section{Additional file 1.}

Additional file 2.

\section{Acknowledgements}

We would like to acknowledge the following persons for supporting our work. Bauhinia srtychnifolia Criab samples were prepared and given to us under supervision of Assoc. Prof. Dr. Surapot Wongyai. Asst. Prof. Dr. Potijanee Srimanote provided cell lines for the whole works. Asst. Prof. Sawanya Pongparit supported us the bacterial strains. Asst. Prof. Weerawat Liemmanee helped us on statistical analyses. Dr. Sukanya Pengpanich gave suggestions on MTT and GSH data interpretation. Nirun Vipunngeun identified and confirmed the species of our plant sources. Lukman Sueree gave advising on microdilution assay. Finally, we would like to acknowledge Marko Žižek who edited the full paper.

\section{Authors' contributions}

SP conducted disc diffusion assay, broth microdilution assay, ABTS assay, LC-MS analysis, and was a major contributor in writing the manuscript. FJ performed MTT assay, microscopic assay, Hoechst 33342 staining, and GSH assay. All authors read and approved the final manuscript.

\section{Funding}

This research did not receive any specific grant from funding agencies in the public, commercial, or not-for-profit sectors.

\section{Availability of data and materials}

The datasets used and/or analysed during the current study are available from the corresponding author on reasonable request. 


\section{Declarations}

\section{Ethics approval and consent to participate}

Nirun Vipunngeun (Lecturer and Botanist, Department of Pharmacognosy, Faculty of Pharmacy, Rangsit University) cultivated and harvested plant materials from Rangsit University's cultivation field with our own permission. He then compared that plant materials with voucher specimen number BK No. 084965 [Additional file 2] of BK Herbarium (Botanical Section, National Department of Agriculture, Thailand) according to the national guideline prior to extract preparation.

\section{Consent for publication}

Not applicable.

\section{Competing interests}

The authors declare that they have no competing interests.

\section{Author details}

${ }^{1}$ Biochemistry Unit, Department of Biomedical Science, Faculty of Sciences, Rangsit University, 52/347 Muang Ake, Phaholyothin road, Lak Hok, Muang, Pathum Thani 12000, Thailand. ${ }^{2}$ Faculty of Medical Technology, Rangsit University, 52/347 Muang Ake, Phaholyothin road, Lak Hok, Muang, Pathum Thani 12000, Thailand.

Received: 3 March 2021 Accepted: 19 October 2021

Published online: 04 November 2021

\section{References}

1. Larsen K, Larsen SS. Leguminosae- Caesalpinioideae. In: Smitinad T, Larsen K, eds. Flora of Thailand. Bangkok, The TISTR Press; 1984:4(1):24

2. Wutthithammavet W. Thai Traditional Medicine, vol. 381. Bangkok: Odean Store Press; 1997.

3. Yuenyongsawad S, Bunluepuech K, Wattanapiromsakul C, Tewtrakul S Anti-cancer activity of compounds from Bauhinia strychnifolia stem. J Ethnopharmacol. 2013;150(2):765-9.

4. Kaewpiboon C, Lirdprapamongkol K, Srisomsap C, Winayanuwattikun $\mathrm{P}$, Yongvanich T, Puwaprisirisan $\mathrm{P}$, et al. Studies of the in vitro cytotoxic, antioxidant, lipase inhibitory and antimicrobial activities of selected Thai medicinal plants. BMC Complement Altern Med. 2012;12:217.

5. Itharat A, Sayompark S, Hansakul P, Dechayont B. In vitro antioxidant activities of extracts of Bauhinia strychnifolia stems and leaves: comparison with activities in green tea extracts. Med Aromat Plants. 2016:5:243.

6. Panchinda C, Ruangnoo S, Itharat A. Cytotoxic activity against cancer cell lines from the ethanolic extracts and its VLC fractions of Bauhinia strychnifolia leaves. J Med Assoc Thail. 2016;99(Suppl 4):S110-5.

7. Bunluepuech K, Tewtrakul S, Wattanapiromsakul C. Alpha-glucosidase inhibitory activity of compounds from Bauhinia strychnifolia. J Chem Pharm Res. 2019:11(6):22-6.

8. Duarte-Almeida JM, Negri G, Salatino A. Volatile oils in leaves of Bauhinia (Fabaceae Caesalpinioideae). Biochem Syst Ecol. 2004;32:747-53.

9. Mosmann T. Rapid colorimetric assay for cellular growth and survival: application to proliferation and cytotoxicity assays. J Immunol Methods. 1983;65(1-2):55-63.

10. McGaw LJ, Jäger AK, van Staden J. Antibacterial, anthelmintic and antiamoebic activity in south African medicinal plants. J Ethnopharmacol. 2000;72(1-2):247-63.

11. van Elsland D, Neefjes J. Bacterial infections and cancer. EMBO Rep. 2018;19(11):e46632.

12. Radovanović BC, Anđelković SM, Radovanović AB, Anđelković MZ. Antioxidant and antimicrobial activity of polyphenol extracts from wild berry fruits grown in Southeast Serbia. Trop J Pharm Res. 2013;12(5):813-9.

13. Aibinu I, Adenipekun T, Adelowotan T, Ogunsanya T, Odugbemi T. Evaluation of the antimicrobial properties of different parts of Citrus aurantifolia (lime fruit) as used locally. Afr J Tradit Complement Altern Med. 2006:4(2):185-90.

14. Radji M, Agustama RA, Elya B, Tjampakasari CR. Antimicrobial activity of green tea extract against isolates of methicillin-resistant Staphylococcus aureus and multi-drug resistant Pseudomonas aeruginosa. Asian Pac J Trop Biomed. 2013;3(8):663-7.

15. Pellegrini N, Colombi B, Salvatore S, Brenna OV, Galaverna G, Rio D, et al Evaluation of antioxidant capacity of some fruit and vegetable foods: efficiency of extraction of a sequence of solvents. J Sci Food Agric. 2007;87:103-11.

16. Preethi KC, Kuttan G, Kuttan R. Antioxidant potential of an extract of Calendula officinalis flowers in vitro and in vivo. Pharm Biol. 2006:44(9):691-7.

17. Shtukmaster $S$, Ljubuncic $P$, Bomzon A. The effect of an aqueous extract of Teucrium polium on glutathione homeostasis in vitro: a possible mechanism of its hepatoprotectant action. Adv Pharmacol Sci. 2010;2010:938324.

18. Fernandes F, Sousa C, Ferreres F, Valentão P, Remião F, Pereira JA, et al. Kale extract increases glutathione levels in $V 79$ cells, but does not protect them against acute toxicity induced by hydrogen peroxide. Molecules. 2012;17(5):5269-88

19. Dose J, Matsugo S, Yokokawa H, Koshida Y, Okazaki S, Seidel U, et al. Free radical scavenging and cellular antioxidant properties of astaxanthin. Int $J$ Mol Sci. 2016:17(1):103.

20. Hsu CC, Kuo HC, Huang KE. The effects of phytosterols extracted from Diascorea alata on the antioxidant activity, plasma lipids, and hematological profiles in Taiwanese menopausal women. Nutrients. 2017;9(12):1320.

21. Ali MA. Molecular docking and molecular dynamics simulation of anticancer active ligand '3,5,7,30,50-pentahydroxy-flavanonol-3-O-a-L-rhamnopyranoside' from Bauhinia strychnifolia Craib to the cyclin-dependent protein kinase. J King Saud Univ Sci. 2020;32:891-5.

22. Babu S, Jayaraman S. An update on $\beta$-sitosterol: a potential herbal nutraceutical for diabetic management. Biomed Pharmacother. 2020;131:110702.

23. Santos AR, Niero R, Filho VC, Yunes RA, Pizzolatti MG, Delle Monache F, et al. Antinociceptive properties of steroids isolated from Phyllanthus corcovadensis in mice. Planta Med. 1995;61(4):329-32.

24. López-Rubalcava C, Piña-Medina B, Estrada-Reyes R, Heinze G, MartínezVázquez M. Anxiolytic-like actions of the hexane extract from leaves of Annona cherimolia in two anxiety paradigms: possible involvement of the GABA/benzodiazepine receptor complex. Life Sci. 2006;78(7):730-7.

25. Dighe SB, Kuchekar BS, Wankhede SB. Analgesic and anti-inflammatory activity of $\beta$-sitosterol isolated from leaves of Oxalis corniculata. Int J of Pharmc Res. 2016:6(3):109-13.

26. Fraile L, Crisci E, Córdoba L, Navarro MA, Osada J, Montoya M. Immunomodulatory properties of beta-sitosterol in pig immune responses. Int Immunopharmacol. 2012;13(3):316-21.

27. Ododo MM, Choudhury MK, Dekebo AH. Structure elucidation of $\beta$-sitosterol with antibacterial activity from the root bark of Malva parviflora. Springerplus. 2016;5(1):1210.

28. Paniagua-Pérez R, Flores-Mondragón G, Reyes-Legorreta C, Herrera-López B, Cervantes-Hernández I, Madrigal-Santillán $\mathrm{O}$, et al. Evaluation of the anti-inflammatory capacity of beta-sitosterol in rodent assays. Afr J Tradit Complement Altern Med. 2016;14(1):123-30.

29. Feng $S$, Gan L, Yang CS, Liu AB, Lu W, Shao P, et al. Effects of stigmasterol and $\beta$-sitosterol on nonalcoholic fatty liver disease in a mouse model: a lipidomic analysis. J Agric Food Chem. 2018;66(13):3417-25.

30. Yuan C, Zhang X, Long $X$, Jin J, Jin R. Effect of $\beta$-sitosterol self-microemulsion and $\beta$-sitosterol ester with linoleic acid on lipid-lowering in hyperlipidemic mice. Lipids Health Dis. 2019;18(1):157.

31. Abdou EM, Fayed MAA, Helal D, Ahmed KA. Assessment of the hepatoprotective effect of developed lipid-polymer hybrid nanoparticles (LPHNPS) encapsulating naturally extracted $\beta$-sitosterol against $\mathrm{CCl}_{4}$ induced hepatotoxicity in rats. Sci Rep. 2019;9(1):19779.

32. Park YJ, Bang IJ, Jeong MH, Kim HR, Lee DE, Kwak JH, et al. Effects of $\beta$-sitosterol from corn silk on TGF- $\beta 1$-induced epithelial-mesenchymal transition in lung alveolar epithelial cells. J Agric Food Chem. 2019:67(35):9789-95.

33. Abbas MM, Al-Rawi N, Abbas MA, Al-Khateeb I. Naringenin potentiated $\beta$-sitosterol healing effect on the scratch wound assay. Res Pharm Sci. 2019;14(6):566-73.

34. Babu S, Krishnan M, Rajagopal P, Periyasamy V, Veeraraghavan V, Govindan $\mathrm{R}$, et al. Beta-sitosterol attenuates insulin resistance in adipose tissue via IRS-1/Akt mediated insulin signaling in high fat diet and sucrose induced type-2 diabetic rats. Eur J Pharmacol. 2020;873:173004 
35. Ponnulakshmi R, Shyamaladevi B, Vijayalakshmi P, Selvaraj J. In silico and in vivo analysis to identify the antidiabetic activity of beta sitosterol in adipose tissue of high fat diet and sucrose induced type-2 diabetic experimental rats. Toxicol Mech Methods. 2019;29(4):276-90.

36. Sharmila R, Sindhu G. Evaluate the antigenotoxicity and anticancer role of $\beta$-sitosterol by determining oxidative DNA damage and the expression of phosphorylated mitogen-activated protein kinases', C-fos, C-Jun, and endothelial growth factor receptor. Pharmacogn Mag. 2017;49:95-101.

37. Kozłowska M, Gruczyńska E, Ścibisz I, Rudzińska M. Fatty acids and sterols composition, and antioxidant activity of oils extracted from plant seeds. Food Chem. 2016;213:450-6.

38. Vivancos M, Moreno JJ. $\beta$-Sitosterol modulates antioxidant enzyme response in RAW 264.7 macrophages. Free Radic Biol Med. 2005;39(1):91-7.
39. Gupta R, Sharma AK, Dobhal MP, Sharma MC, Gupta RS. Antidiabetic and antioxidant potential of $\beta$-sitosterol in streptozotocin-induced experimental hyperglycemia. J Diabetes. 2011;3(1):29-37.

40. Ayaz M, Junaid M, Ullah F, Subhan F, Sadiq A, Ali G, et al. Anti-Alzheimer's studies on $\beta$-sitosterol isolated from Polygonum hydropiper L. Front Pharmacol. 2017;8:697.

\section{Publisher's Note}

Springer Nature remains neutral with regard to jurisdictional claims in published maps and institutional affiliations.
Ready to submit your research? Choose BMC and benefit from:

- fast, convenient online submission

- thorough peer review by experienced researchers in your field

- rapid publication on acceptance

- support for research data, including large and complex data types

- gold Open Access which fosters wider collaboration and increased citations

- maximum visibility for your research: over 100M website views per year

At BMC, research is always in progress.

Learn more biomedcentral.com/submissions 